\title{
PCDD/F formation from chlorophenols by lignin and manganese peroxidases
}

\author{
M. MUÑOZ1 , M.F. GOMEZ-RICO, R. FONT
}

Department of Chemical Engineering, University of Alicante, P.O. Box 99, E-03080

\section{Alicante}

\section{Abstract}

Polychlorinated dibenzo-p-dioxins and polychlorinated dibenzofurans (PCDD/F) formation was studied, in vitro, with two different chlorophenol mixtures (group "di+tri" 2,4-dichlorophenol; 2,3,4-, 2,3,5-, and 3,4,5-trichlorophenols and group "tri+tetra+penta" with 2,4,5-trichlorophenol, 2,3,4,6-tetrachlorophenol and pentachlorophenol) and two different lignolytic enzymes, lignin and manganese peroxidase (LiP and $\mathrm{MnP}$ respectively), which can be found during the composting process of sewage sludge. The concentrations of PCDD/F in final samples are compared to the $\mathrm{PCDD} / \mathrm{F}$ content of the control samples containing the chlorophenols. High increases were observed for experiments with $\mathrm{MnP}$ and phosphate buffer. Experiments that contained tri-, tetra- and pentachlorophenol with MnP resulted in more than $8 \cdot 10^{8}$ ng of OCDD kg-1 chlorophenol which was much higher than the initial amount $\left(1 \cdot 10^{7}\right.$ ng OCDD kg-1 chlorophenol). In relation to $\mathrm{LiP}$ experiments, only those at $37{ }^{\circ} \mathrm{C}$ showed a moderate increase (from $1.3 \cdot 10^{7}$ to $2.6 \cdot 10^{7} \mathrm{ng}$ of OCDD kg-1 chlorophenol). The results agree with the literature in which high amounts of HpCDD and OCDD were found after a composting process and could explain the biogenic formation suggested by others, but the incidence on the total toxicity is less than that expected.

\footnotetext{
${ }^{1}$ Corresponding author. Tel. + 34965903400 - ext. 3003; Fax Nr: + 34965903826.

E-mail address: maria.munoz@ua.es (María Muñoz)
} 
Keywords: compost, sewage sludge, manganese peroxidase, lignin peroxidase, enzyme, PCDD/F.

\section{Introduction}

Composting is a well-extended practice of waste reduction that consists of a microbial conversion of material in the presence of suitable amounts of air and moisture into a stabilized product, compost, with the general appearance and other characteristics of a fertile soil. Compost is used as a soil amendment and fertilizer since it is a source of macro and micronutrients to plant growth. According to the composting definition, the organic compounds during the process should be reduced or eliminated, but an increase in the PCDD/F content (especially HpCDDs and OCDD) in compost from sewage sludge has been well documented in previous studies (Hamann et al., 1997; Weber et al., 1997; Gómez-Rico et al., 2007). Malloy et al. (1993) also found high concentrations of PCDD/Fs (toxic equivalency mean value of $56 \mathrm{ng}$ I-TEQ $\mathrm{kg}^{-1}$ ) during the composting process of municipal solid waste (MSW), MSW mixed with sewage sludge and yard waste composting, where $1,2,3,4,6,7,8$-HpCDD and OCDD were again the dominant congeners. However, Concejero et al. (2008) after studying three MSW composting facilities found values of $1.53-5.26 \mathrm{ng}$ WHO-TEQ $\mathrm{kg}^{-1}$ (or 2.92-9.22 ng ITEQ $\mathrm{kg}^{-1}$ ) which were lower than the initial content.

Therefore, the increase or decrease of the PCDD/F levels during composting seems to depend on the process conditions and initial materials containing PCDD/F precursors. In compost from sewage sludge the precursors necessary for the PCDD/F formation could be introduced to the process through the initial materials, such as sawdust used as a bulking agent that could contain pentachlorophenol (PCP). PCP was used for many years as fungicide to treat wood to avoid woodworm, biocide and herbicide, but nowadays its use is limited because of its relationship with the formation of PCDD/Fs. 
47 It has been observed that PCP is the most contaminated pesticide with these compounds 48 (PCDD/Fs). Sewage sludge used for composting could also contain other kind of

chlorophenols (CPs). CPs can be also found in leachates from MSW landfills (Ozkaya, 2005) and therefore they can be present in the MSW compost process.

CPs can be transformed into PCDD/Fs by an enzymatic reaction as reported in literature and this can occur during the composting process of sewage sludge. A group of researchers (Öberg et al., 1987) firstly studied the biological formation of PCDD/Fs from lactoperoxidase (LP) and chlorophenols but without finding PCDD/F formation. Svenson et al. (1989) seem to be the first group in finding that 2,3,7,8-tetrasubtituted congeners were formed in the reaction of 2,4,5-trichlorophenol with horseradish peroxidase (HRP) at $20^{\circ} \mathrm{C}$, mainly tetra-, penta- and hexachloro derivates. Öberg et al. (1990) studied the reaction of 3,4,5- and 2,4,5-trichlorophenol in the presence of bovine lactoperoxidase (LP) as well as HRP, and hydrogen peroxide at room temperature, where the major products were 1,2,3,6,7,8-HxCDD, 1,2,4,7,8-PeCDD and 1,2,4,6,7,9HxCDD and agreeing, in part, with Svenson's results. In another study, the same group of researchers tested eight chlorophenols with HRP and LP, all of them resulting in PCDD/Fs formation. Especially a high amount of OCDD was obtained in the experiment with PCP (Öberg et al., 1992). The concentration of PCDD/Fs in their experiments was two- to ten-times higher after the reaction and regarding the initial mixture, depending on the congener. Also Wagner et al. (1990) experimented with 2,4,5-tricholorophenol (triCP) and HRP, finding high amounts of PCDD/F formation. Wittsiepe et al. (2000) studied the transformation of 2,4,5-tri-, 2,3,4,6-tetra-, pentachlorophenol and mixtures of them with plant HP and myeloperoxidase, in the presence of hydrogen peroxide. The yield, the reaction, and the PCDD/F-pattern found depended on the CPs and it could be pointed out that higher yields of OCDD were 
obtained in the experiments where pentachlorophenol was involved, as found by Öberg (1992; 1993). The results of Öberg could explain the relatively high concentration of OCDD and HpCDD also found in compost samples studies (Hamann et al., 1997; Weber et al., 1997; Gómez-Rico et al., 2007).

Experiments "in vivo" are also found in literature. Huwe et al. (2000) investigated the formation of dioxins from pentachlorophenol and predioxin nonachloro-2phenoxyphenol in rats. They concluded that predioxin is the compound which leads to a formation of OCDD instead of pentachlorophenol. Nonachloro-2-phenoxyphenol is an impurity present in pentachloropehol and other pesticides.

Besides the aforementioned findings, it should be mentioned here that other authors also found PCDD/F degradation by means of biological activity. A group of researchers (Chang, 2008) tried to elucidate the mechanism of the degradation. Suhara et al. (2011) reported the degradation of 2,7-PCDD by some fungi belonging to genera Coprinus.

Field et al. (2008) studied the degradation of PCDD by rot-fungi and also reported possible formation of them from chlorophenols.In this study, two different enzymes (not studied before) were used, manganese and lignin peroxidases ( $\mathrm{MnP}$ and LiP respectively) which can be present in compost. They are lignolytic enzymes typically secreted by White-rot fungi (such as Phanerochaete chrysosporium), as reported in literature (Gold et al., 1989; Lankinen et al., 2001; Quintero et al., 2006).

The white-rot fungi are a physiological rather than taxonomic grouping, comprising those fungi that are capable of extensively degrading lignin (Pointing, 2001). They can be commonly found in wood, as reported in literature (Lankinen et al., 2001) and grow at temperatures of $36-45^{\circ} \mathrm{C}$ (Tuomela et al., 2000). White-rot fungi degrade lignin by means of oxidative enzymes. Because of the nature and size of the lignin molecule, the enzymes responsible for the initial attack must be extracellular and non-specific. The 
97 role of $\mathrm{LiP}$ and $\mathrm{MnP}$ in lignin degradation has been verified, while that of other enzymes is still uncertain (Hatakka, 1994). The catalytic action of their extracellular enzymes can be used for biodegradation of organic pollutants, such as polycyclic aromatic hydrocarbons (PAHs) and polychlorinated biphenyls (PCBs) (Novotný et al., 2004; Oleszczuk, 2007), but the degradation of these compounds could lead to potential precursors for the dioxin formation. These fungi can produce $\mathrm{H}_{2} \mathrm{O}_{2}$ necessary for the enzyme to produce the activity (Öberg et al., 1992).

Agaricus bisporus is a non-white rot and typically litter degrading fungus known to also produce lignin-degrading peroxidases and typically grows on straw-and-hay based compost under standard conditions of the composting process (Bonnen et al., 1994; Lankinen et al., 2001).

As reported in literature both fungi, White-rot fungi and Agaricus bisporus can be found in compost (ten Have et al., 2003) and therefore the enzymes LiP and MnP. Alam et al. (2009) produced lignin peroxidase by white-rot fungi using sewage sludge as a major substrate.

Peroxidases are bi-substrate enzymes that require $\mathrm{H}_{2} \mathrm{O}_{2}$ for the oxidation of CPs into chlorophenoxy radicals. PCDD/Fs are subsequently formed by condensation (Öberg, 1992). $\mathrm{H}_{2} \mathrm{O}_{2}$ is present in low concentrations in fungal cultures. The oxidation characteristics of these ligninolytic enzymes are reported elsewhere (Mester et al., 2000; Eibes et al., 2005; Eibes et al., 2006). The main function of MnP is to catalyze the oxidation of $\mathrm{Mn}^{2+}$ to $\mathrm{Mn}^{3+}$, for which $\mathrm{H}_{2} \mathrm{O}_{2}$ is required (Feijoo et al., 2008). The $\mathrm{Mn}^{3+}$ ion is a strong oxidant and can act on a great variety of phenolic compounds. CPs are good substrates for $\mathrm{MnP}$ as previously reported (Sedarati et al., 2003). Its activity is highly increased with malonate buffer and $\mathrm{MnSO}_{4}$ to provide $\mathrm{Mn}^{2+}$. On the other hand, 
121 LiP catalyzes the one-electron oxidation of aromatic compounds by a mechanism

122 involving the formation of substrate aryl cation radical.

123 In spite of the several studies showing that some other peroxidases such as

124 horseradish and lactoperoxidase catalyze the formation of PCDD/Fs through precursors

125 or predioxins (Öberg et al., 1992; Wittsiepe et al., 2000), no studies have been done

126 with $\mathrm{LiP}$ and $\mathrm{MnP}$ which can be present in the composting process. The aim of this

127 work was to investigate the "in vitro" formation of PCDD/F from two mixtures of 128 chlorophenols catalyzed by two different enzymes, LiP and MnP in the presence of 129 hydrogen peroxide, thus simulating the reactions which could take place during 130 composting of sewage sludge. The reactions were carried out with two different 131 temperatures and two buffer solutions in order to have the best conditions for the 132 reaction of enzymes involved.

$133 \quad$ Materials and methods

Reactants

Lignin peroxidase (LiP, EC 1.11.1.14) and manganese peroxidase (MnP, EC 1.11.1.13) were purchased from Sigma-Aldrich. All the chlorophenols were also purchased from Sigma-Aldrich. The following compounds: 2,4,5- , 3,4,5- and 2,3,5trichlorophenol and 2,3,4,6-tetrachlorophenol were analytical standard grade and these three compounds, 2,3,4-trichlorophenol, pentachlorophenol and 2,4-dichlorophenol

140 were $99 \%$ certified. Stock solutions of the chlorophenols were made in methanol in 141 concentrations ranging $0.10-0.15 \mathrm{~mol} \mathrm{~L}^{-1}$. The working solutions ranged from 0.006 to $0.015 \mathrm{~mol} / \mathrm{l}$. 
Four control samples were prepared as follows. Two of them, containing either LiP

147 or MnP and all other reactants except the chlorophenols, another one containing the

148 chlorophenol mixture di+tri without enzyme and the last one, containing the

149 chlorophenol mixture tri+tetra+penta and no enzyme (see Table 1). These four control

150 samples were analyzed to determine the initial PCDD/F content in the reactants and

151 compare it with the final samples.

152

In vitro reactions

153

For each enzyme four experiments were performed in order to study different conditions and compare the results. The procedure was based on that previously used by other authors with horseradish and myeloperoxidase (Wittsiepe et al., 2000). On the one hand, four experiments were carried out with a mixture of di- and tri-

157 chlorophenols, containing specifically 2,4-dichlorophenol, 2,3,4-trichlorophenol, 2,3,5trichlorophenol and 3,4,5-chlorophenol (they will be named as " $d i+t r i "$ and correspond to experiments 1 to 4 in Table 1). On the other hand, another group of four experiments consisted of a mixture containing 2,4,5-trichlorophenol, 2,3,4,6-

161 tetrachlorophenol and pentachlorophenol (they will be named as "tri + tetra + penta"

162 and correspond to experiments 5 to 8). The experimental temperatures were $25^{\circ} \mathrm{C}$ and

$16337^{\circ} \mathrm{C}$. Temperature $25^{\circ} \mathrm{C}$ was chosen as it was the recommended temperature by the supplier for the higher enzymatic activity of $\mathrm{MnP}$ and also for $\mathrm{MnP}$ formation from Agaricus bisporus (Lankinen et al., 2005). Experiments at $37^{\circ} \mathrm{C}$ were done at the end of

166 all the experiments and after having seen that there was no enzymatic activity in 167 experiments with $\mathrm{LiP}$ at $25^{\circ} \mathrm{C}$. This temperature is also recommended in the literature 168 for experiments with other peroxidases (Wittsiepe et al., 2000). The different 
170 all of them with a total volume of $2 \mathrm{ml}$..

171 Table 1. Experimental conditions and name of the experiments*.* Experiments are

172 numbered from 1 to 8 . Control samples for MnP and LiP are indicated as MnP and LiP

173 respectively. Control samples for the chlorophenols are indicated as "di+tri" for the

174 mixture with 2,4-dichlorophenol, 2,3,4-trichlorophenol, 2,3,5-trichlorophenol and 3,4,5-

175 chlorophenol and "tri + tetra + penta" for 2,4,5-trichlorophenol, 2,3,4,6-

176 tetrachlorophenol and pentachlorophenol. A means Acetone and EG ethylene glycol.

177 Malon means malonate buffer and Phosp means phosphate buffer. "Yes" or "-." are

178 written to indicate reactant $\left(\mathrm{MnSO}_{4}\right.$ or $\left.\mathrm{H}_{2} \mathrm{O}_{2}\right)$ was used or not.

\begin{tabular}{|c|c|c|c|c|c|c|c|c|c|c|c|c|}
\hline & \multirow{2}{*}{\multicolumn{3}{|c|}{ Control }} & 1 & 2 & 3 & 4 & \multirow[b]{2}{*}{ Control } & 5 & 6 & 7 & 8 \\
\hline & & & & di+tri, & di+tri, & di+tri, & di+tri, & & \multirow{2}{*}{$\begin{array}{c}\text { tri+tetra+ } \\
\text { penta, } \\
\mathrm{MnP}, \\
\text { Malon, } \\
25^{\circ} \mathrm{C}\end{array}$} & \multirow{2}{*}{$\begin{array}{c}\text { tri+tetra+ } \\
\text { penta, } \\
\text { MnP, } \\
\text { Phosp, } \\
25^{\circ} \mathrm{C}\end{array}$} & \multirow{2}{*}{$\begin{array}{c}\text { tri+tetra } \\
\text { +penta, } \\
\text { LiP, } \\
\text { Phosp, } \\
25^{\circ} \mathrm{C}\end{array}$} & \multirow{2}{*}{$\begin{array}{c}\text { tri+tetra } \\
\text { +penta, } \\
\text { LiP, } \\
\text { Phosp, } \\
37^{\circ} \mathrm{C}\end{array}$} \\
\hline & $\mathrm{MnP}$ & $\mathrm{LiP}$ & "di+tri" & $\begin{array}{l}\text { Malon, } \\
25^{\circ} \mathrm{C}\end{array}$ & $\begin{array}{l}\text { Phosp, } \\
25^{\circ} \mathrm{C}\end{array}$ & $\begin{array}{l}\text { Phosp, } \\
25^{\circ} \mathrm{C}\end{array}$ & $\begin{array}{l}\text { Phosp, } \\
37^{\circ} \mathrm{C}\end{array}$ & $\begin{array}{l}\text { "tri+tetra } \\
+ \text { penta" }\end{array}$ & & & & \\
\hline CPs & - & - & \multicolumn{5}{|c|}{ Chlorophenols: "di+tri" } & \multicolumn{5}{|c|}{ "tri+tetra+penta" } \\
\hline Buffer & Malon & Phosp & Malon & Malon & Phosp & Phosp & Phosp & Phosp & Malon & Phosp & Phosp & Phosp \\
\hline $\mathrm{T}\left({ }^{\circ} \mathrm{C}\right)$ & 25 & 25 & 25 & 25 & 25 & 25 & 37 & 25 & 25 & 25 & 25 & 37 \\
\hline Enzyme & $\mathrm{MnP}$ & LiP & - & $\mathrm{MnP}$ & $\mathrm{MnP}$ & LiP & LiP & - & $\mathrm{MnP}$ & $\mathrm{MnP}$ & LiP & LiP \\
\hline $\mathrm{MnSO} 4$ & yes & - & - & yes & yes & - & - & - & yes & yes & & \\
\hline $\mathrm{H}_{2} \mathrm{O}_{2}$ & yes & yes & yes & yes & yes & yes & yes & yes & yes & yes & yes & yes \\
\hline Solvent & $\mathrm{A}$ & E.G. & $\mathrm{A}$ & $\mathrm{A}$ & $\mathrm{A}$ & EG & EG & A & $\mathrm{A}$ & $\mathrm{A}$ & EG & EG \\
\hline
\end{tabular}

179

All reactions were carried out in a buffer solution. The buffer solution used for

experiments numbered from 2 to 4 and from 6 to 8 was phosphate (indicated as Phosp),

$\mathrm{KH}_{2} \mathrm{PO}_{4} / \mathrm{K}_{2} \mathrm{HPO}_{4}(\mathrm{pH}=5.4)$, and malonate, $\mathrm{C}_{3} \mathrm{H}_{4} \mathrm{O}_{4} / \mathrm{NaOH}(\mathrm{pH}=4.5)$ for experiments

1831 and 5 (indicated as Malon).

Acetone or ethylene glycol was added to the reaction mixture up to a total volume of

$1852 \mathrm{ml}$ to increase the solubility of chlorophenols due to their low solubility in water

186 (Czaplicka, 2004). Some solvents, such as methanol which was used to dissolve the

187 chlorophenols, deactivate the enzyme MnP, therefore acetone is used instead (Eibes et

188 al., 2005). Ethylene glycol was used for the experiments with $\mathrm{LiP}$ as it enhances the

189 catalytic activity of this enzyme (Yoshida et al., 1997). When $\mathrm{MnP}$ was used, $\mathrm{MnSO}_{4}$ at

190 a concentration of $20 \cdot 10^{-6} \mathrm{M}$ was also added to the reaction mixture to provide the $\mathrm{Mn}^{2+}$ 
191 ions which were needed to prevent the dismutation of $\mathrm{Mn}^{3+}$ to $\mathrm{MnO}_{2}$ and $\mathrm{Mn}^{2+}$ and to

192 keep $\mathrm{Mn}^{3+}$ as a catalytic agent to oxidize the compounds (Feijoo et al., 2008).

193 The reaction was started when the hydrogen peroxide is added and the incubation

194 time was about 40 hours. The incubation time is much longer than the one suggested by 195 others (Öberg et al., 1987; Wittsiepe et al., 2000), due to the lower enzymatic activity of 196 the experiments in this study.

$\mathrm{PCDD} / \mathrm{F}$ analysis

After the incubation time, the analytical procedure began. A standard solution 199 containing $17{ }^{13} \mathrm{C}_{12}$ labeled PCDD/F congeners was added to the reaction solution and $\mathrm{Na}_{2} \mathrm{SO}_{4}$ was added to remove the water content. Then the samples were extracted in toluene using accelerated solvent extraction with a Dionex 100 apparatus (Dionex 202 Corp., CA, USA). The extract is solvent exchanged to hexane and extraction with 203 sulfuric acid is done to remove the chlorophenols. The extract was dried by filtering with $\mathrm{Na}_{2} \mathrm{SO}_{4}$ and then it was cleaned and purified with an automated clean-up system, Power Prep equipment (FMS Inc., Boston, MA). spectrometer (Micromass, UK), with a positive electron impact (EI+) source and interfaced with a Hewlett-Packard (Palo Alto, CA, USA) 6890 Plus gas chromatograph equipped with a PTV (Programmable Temperature Vaporizing) inlet with a septumpless head. An Rtx® Dioxin2 (60 m x $0.25 \mathrm{~mm}$ x $0.25 \mu \mathrm{m})$ fused silica capillary column was

211 used for the separation of the isomer specific analysis. Prior to the injection a recovery 212 standard was added. Identification and quantification of each PCDD/F congener was performed by the isotope dilution method, based on the US EPA Method for PCDD/F determination (US EPA, 1994). 
Quality assurance and quality control (QA/QC) criteria included the recovery percentage of the internal standards, the relative retention time of the target compound

217 compared to the internal standard, and the chlorine isotope ratio falling within $15 \%$ of the theoretical chlorine isotope ratio when the two most abundant ions are measured. Additional QA/QC included a laboratory blank that gave results below the detection limit. Regarding the recovery percentage, all the samples were within the established limits of the method (US EPA, 1994). According to previous experiments and laboratory tests carried out by the research group the uncertainty of the measure was estimated in $15 \%$ for values higher than $10 \times 10^{4} \mathrm{ng} \mathrm{kg}^{-1}$ and $1 \mathrm{ng} \mathrm{kg}^{-1}$ for smaller values. The uncertainty in the TEQ values was estimated in $1 \mathrm{ng}_{-} \mathrm{kg}^{-1}$. This uncertainty is based on previous experiments and on the experimental background of the group and comprises the possible errors that can occur during the analytical procedure and also by the equipments.

\section{Results}

The control samples containing the enzymes, LiP and MnP respectively, and not containing the chlorophenols resulted in levels near or below the detection limit and were negligible compared with the results of the experiments. On the other hand, the control samples containing the CPs mixtures showed considerable amounts of PCDD/F, thus indicating that CPs were contaminated with PCDD/Fs. Therefore, all the experiments are compared to these control samples in order to show the increase in the concentration after the reaction.

The concentrations in $\mathrm{ng} \mathrm{kg}^{-1} \mathrm{CP}$ and total TEQ concentration for all congeners for initial samples and experiments are shown in Table 2 and Table 3, where $\Sigma$ 2,3,7,8 PCDD/Fs refers to the sum of all the 2,3,7,8-tetrasubstituted congeners while Total 
240 contribution is mainly due to the toxic congeners. Total $2,3,7,8-\mathrm{PCDD} / \mathrm{F}$ concentrations

241 range between $2.4 \cdot 10^{6}$ and $1.2 \cdot 10^{9} \mathrm{ng} \mathrm{kg}^{-1} \mathrm{CP}$ for experiments "di+tri, MnP, Malonate,

$24225^{\circ} \mathrm{C}$ " and "tri+tetra+penta, MnP, Phosphate, $25^{\circ} \mathrm{C}$ respectively.

243 Table 2. Concentrations in $\mathrm{ng} \mathrm{kg}^{-1} \times 10^{4} \mathrm{CP}$ for all the congeners in experiments with 244 "di+tri" mixture (see nomenclature in Table 1).

\begin{tabular}{|c|c|c|c|c|c|}
\hline & Control & 1 & 2 & 3 & 4 \\
\hline & & & & & \\
& di+tri & $\begin{array}{c}\text { di+tri, MnP, } \\
\text { Malon, } 25^{\circ} \mathrm{C}\end{array}$ & $\begin{array}{c}\text { di+tri, MnP, } \\
\text { Phosp, } 25^{\circ} \mathrm{C}\end{array}$ & $\begin{array}{c}\text { di+tri, LiP, } \\
\text { Phosp, } 25^{\circ} \mathrm{C}\end{array}$ & $\begin{array}{c}\text { di+tri, LiP, } \\
\text { Phosp, } 37^{\circ} \mathrm{C}\end{array}$ \\
\hline $2,3,7,8-\mathrm{TCDF}$ & 0.2 & 0.02 & 0.1 & 0.08 & 0.04 \\
$1,2,3,7,8-\mathrm{PeCDF}$ & 1.4 & 0.1 & 0.2 & 0.28 & 0.14 \\
$2,3,4,7,8-\mathrm{PeCDF}$ & 1.4 & 0.1 & 0.6 & 0.32 & 0.17 \\
$1,2,3,4,7,8-\mathrm{HxCDF}$ & 1.8 & 0.1 & 0.6 & 0.38 & 0.23 \\
$1,2,3,6,7,8-\mathrm{HxCDF}$ & 1.3 & 0.1 & 6.4 & 0.42 & 0.23 \\
$2,3,4,6,7,8-\mathrm{HxCDF}$ & 1.9 & 0.1 & 116.0 & 0.44 & 0.21 \\
$1,2,3,7,8,9-\mathrm{HxCDF}$ & 1.4 & 0.2 & 0.9 & 0.50 & 0.17 \\
$1,2,3,4,6,7,8-\mathrm{HpCDF}$ & 2.3 & 1.3 & 37.6 & 0.99 & 0.57 \\
$1,2,3,4,7,8,9-\mathrm{HpCDF}$ & 1.8 & 0.2 & 104.1 & 0.17 & 0.11 \\
OCDF & 2.8 & 8.8 & 25.2 & 2.38 & 0.85 \\
$2,3,7,8-\mathrm{TCDD}$ & 0.4 & 0.2 & 0.6 & 0.50 & 0.20 \\
$1,2,3,7,8-\mathrm{PeCDD}$ & 1.2 & 0.5 & 0.8 & 0.71 & 0.56 \\
$1,2,3,4,7,8-\mathrm{HxCDD}$ & 1.8 & 0.1 & 0.4 & 0.18 & 0.17 \\
$1,2,3,6,7,8-\mathrm{HxCDD}$ & 1.7 & 1.6 & 2.6 & 0.69 & 0.36 \\
$1,2,3,7,8,9-\mathrm{HxCDD}$ & 1.1 & 0.5 & 1.1 & 0.44 & 0.21 \\
$1,2,3,4,6,7,8-\mathrm{HpCDD}$ & 2.8 & 30 & 84 & 1.32 & 0.93 \\
OCDD & 11.3 & 138 & 490 & 6.33 & 5.65 \\
\hline$\Sigma 2,3,7,8$ PCDF & 16.4 & 11 & 292 & 6.0 & 2.7 \\
\hline$\Sigma 2,3,7,8$ PCDD & 20.2 & 171 & 580 & 10.2 & 8.1 \\
\hline$\Sigma 2,3,7,8$ PCDD/Fs & 37 & 182 & 872 & 16 & 11 \\
\hline TOTAL PCDD/Fs & 72 & 245 & 1378 & 36 & 22 \\
\hline WHO2005 TEQ & 3 & 1.4 & 17 & 1.7 & 1.0 \\
\hline
\end{tabular}


In view of Table 2, it can be observed that the concentration of HpCDD and OCDD 250 increases in both experiments with $\mathrm{MnP}$ at $25{ }^{\circ} \mathrm{C}$ with an important increase for the 251 OCDD from $11.3 \cdot 10^{4} \mathrm{ng} \mathrm{kg}^{-1}$ to $490 \cdot 10^{4} \mathrm{ng} \mathrm{kg}^{-1}$ in experiment with Phosphate buffer. It 252 can also be observed a remarkable increment of $2,3,4,6,7,8-\mathrm{HpCDF}$ and $1,2,3,4,7,8,9-$ 253 HpCDD. OCDF slightly increases in the same experiments. Regarding the 254 concentrations of other congeners and taking into account the estimated uncertainties 255 previously commented, it can be said that their variations are negligible. Experiments 256 with LiP did not reveal variations when compared to the control samples.

257 With respect to the toxic concentrations, there is a remarkable increase in 258 experiment with $\mathrm{MnP}$ and Phosphate, but due to the higher toxicity value of 2,3,4,6,7,8259 HxCDF compared to HpCDD and OCDD, the toxicity increase is mainly due to this 260 congener.

261 From Table 3, it can be deduced that there is an important increase of HpCDD and 262 OCDD in experiments with MnP as it also occurs with "di+tri" mixture. The higher 263 increase is observed in experiment with Phosphate buffer too. On the contrary, no increase is observed for PCDFs as it occurs with "di+tri", but a remarkable increase is observed in 1,2,3,6,7,8-HxCDD. 
272 Table 3. Concentrations in $\mathrm{ng} \mathrm{kg}^{-1} \times 10^{4} \mathrm{CP}$ for all the congeners in experiments with

273 "tri+tetra+penta" mixture (see nomenclature in Table 1).

274

\begin{tabular}{|c|c|c|c|c|c|}
\hline & Control & 5 & 6 & 7 & 8 \\
\hline & $\begin{array}{c}\text { tri+ } \\
\text { tetra+ } \\
\text { penta }\end{array}$ & $\begin{array}{c}\text { tri+tetra+ } \\
\text { penta, MnP, } \\
\text { Malon., } 25^{\circ} \mathrm{C}\end{array}$ & $\begin{array}{c}\text { tri+tetra+ penta, } \\
\text { MnP, Phosp, 25 } \\
{ }^{\circ} \mathrm{C}\end{array}$ & $\begin{array}{c}\text { tri+tetra+ } \\
\text { penta, LiP, } \\
\text { Phosp, } 25^{\circ} \mathrm{C}\end{array}$ & $\begin{array}{c}\text { tri+tetra+ } \\
\text { penta, LiP, } \\
\text { Phosp, } 37^{\circ} \mathrm{C}\end{array}$ \\
\hline $2,3,7,8-\mathrm{TCDF}$ & 0.04 & 0.03 & 0.3 & 0.04 & 0.1 \\
$1,2,3,7,8-\mathrm{PeCDF}$ & 0.14 & 0.1 & 0.9 & 0.4 & 0.4 \\
$2,3,4,7,8-\mathrm{PeCDF}$ & 0.19 & 0.1 & 1.1 & 0.4 & 0.4 \\
$1,2,3,4,7,8-\mathrm{HxCDF}$ & 1.88 & 1.8 & 3.0 & 2.2 & 2.0 \\
$1,2,3,6,7,8-\mathrm{HxCDF}$ & 0.40 & 0.3 & 1.6 & 0.8 & 0.6 \\
$2,3,4,6,7,8-\mathrm{HxCDF}$ & 0.68 & 0.6 & 1.5 & 1.0 & 1.0 \\
$1,2,3,7,8,9-\mathrm{HxCDF}$ & 0.39 & 0.2 & 1.5 & 0.7 & 0.1 \\
$1,2,3,4,4,6,8-\mathrm{HpCDF}$ & 287 & 301.0 & 301.0 & 283 & 273 \\
$1,2,3,4,7,8,9-\mathrm{HpCDF}$ & 13 & 13.2 & 18.5 & 13 & 13 \\
OCDF & 2900 & 2700 & 3580 & 2700 & 2710 \\
$2,3,7,8-\mathrm{TCDD}$ & 1.32 & 1.5 & 1.6 & 1.5 & 1.5 \\
$1,2,3,7,8-\mathrm{PeCDD}$ & 0.19 & 0.1 & 1.5 & 0.4 & 0.3 \\
$1,2,3,4,7,8-\mathrm{HxCDD}$ & 0.14 & 0.4 & 12.1 & 0.4 & 0.4 \\
$1,2,3,6,7,8-\mathrm{HxCDD}$ & 7.83 & 13.3 & 200.0 & 8.4 & 8.1 \\
$1,2,3,7,8,9-\mathrm{HxCDD}$ & 0.40 & 1.9 & 64.7 & 0.8 & 0.7 \\
$1,2,3,4,6,7,8-\mathrm{HpCDD}$ & 243 & 1020 & 11900 & 245 & 333 \\
OCDD & 1350 & 660 & 86200 & 1370 & 2600 \\
\hline$\Sigma 2,3,7,8$ PCDF & 3203 & 3017 & 3909 & 3002 & 3000 \\
\hline$\Sigma 2,3,7,8$ PCDD & 1603 & 1697 & 98380 & 1627 & 2944 \\
\hline$\Sigma 2,3,7,8$ PCDD/Fs & 4806 & 4715 & 102289 & 4628 & 5945 \\
\hline TOTAL PCDD/Fs & 6660 & 13793 & 121672 & 6443 & 7878 \\
\hline WHO2005 TEQ & 9 & 20 & 181 & 10 & 11 \\
\hline
\end{tabular}

In experiment "tri+tetra+penta, MnP, Phosphate/Malonate and $25^{\circ} \mathrm{C}$ " the $2,3,7,8$ -

278 tetrasubstituted congeners contribute to more than $70 \%$ to the total concentration in

279 experiments. There is also a considerable increase in the toxicity, expressed as ng

$280 \mathrm{WHO}_{2005} \mathrm{TEQ} / \mathrm{kg}$ chlorophenol in this experiment. This is due to the HpCDD and

281 OCDD congeners. Note also that the concentration of $1,2,3,7,8,9-\mathrm{HxCDD}$ was more

282 than $6 \cdot 10^{5} \mathrm{ng} \mathrm{kg}^{-1} \mathrm{CP}$ which was much higher than the initial concentration $\left(4 \cdot 10^{3} \mathrm{ng}\right.$ 
$283 \mathrm{~kg}^{-1} \mathrm{CP}$ ) in experiment "tri+tetra+penta, MnP, Phosphate, $25^{\circ} \mathrm{C}$. Again, experiments 284 with Lip did not report an increase.

285

\section{Discussion}

286 With the objective of discussing the results, Figure 1 and Figure 2 are presented.

287 These figures show the absolute concentration of the major PCDD/F congeners in $\mathrm{ng} / \mathrm{kg}$ 288 of chlorophenols (ng kg-1 CPs) for the experiments with "di+tri" and "tri+tetra+penta" 289 chlorophenols group respectively. The increase of each congener can be observed 290 comparing the color bars with the white bars (control sample). 


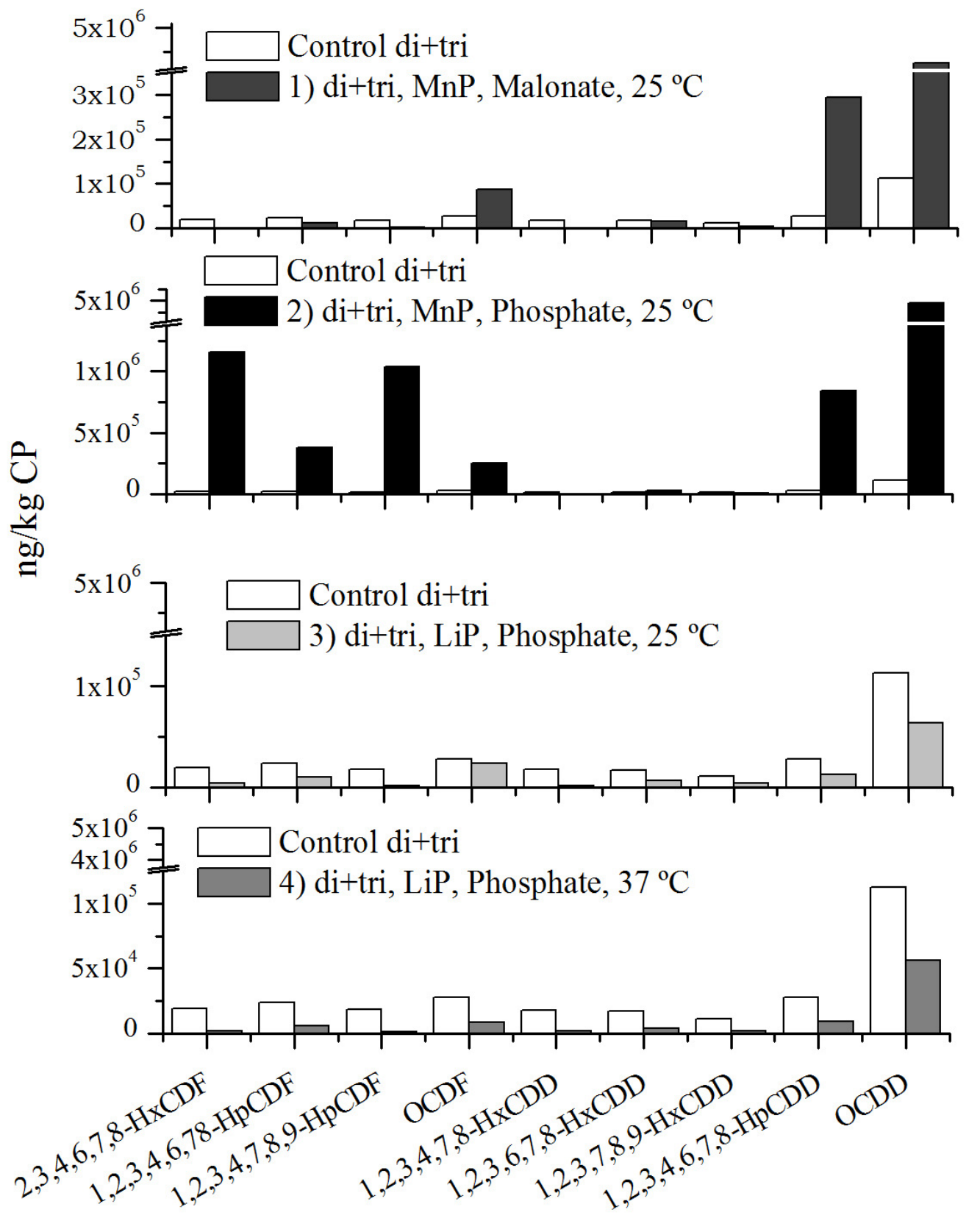

Figure 1. Concentration of the most abundant congeners in $\mathrm{ng} / \mathrm{kg}$ chlorophenol for the mixtures "di+tri". 

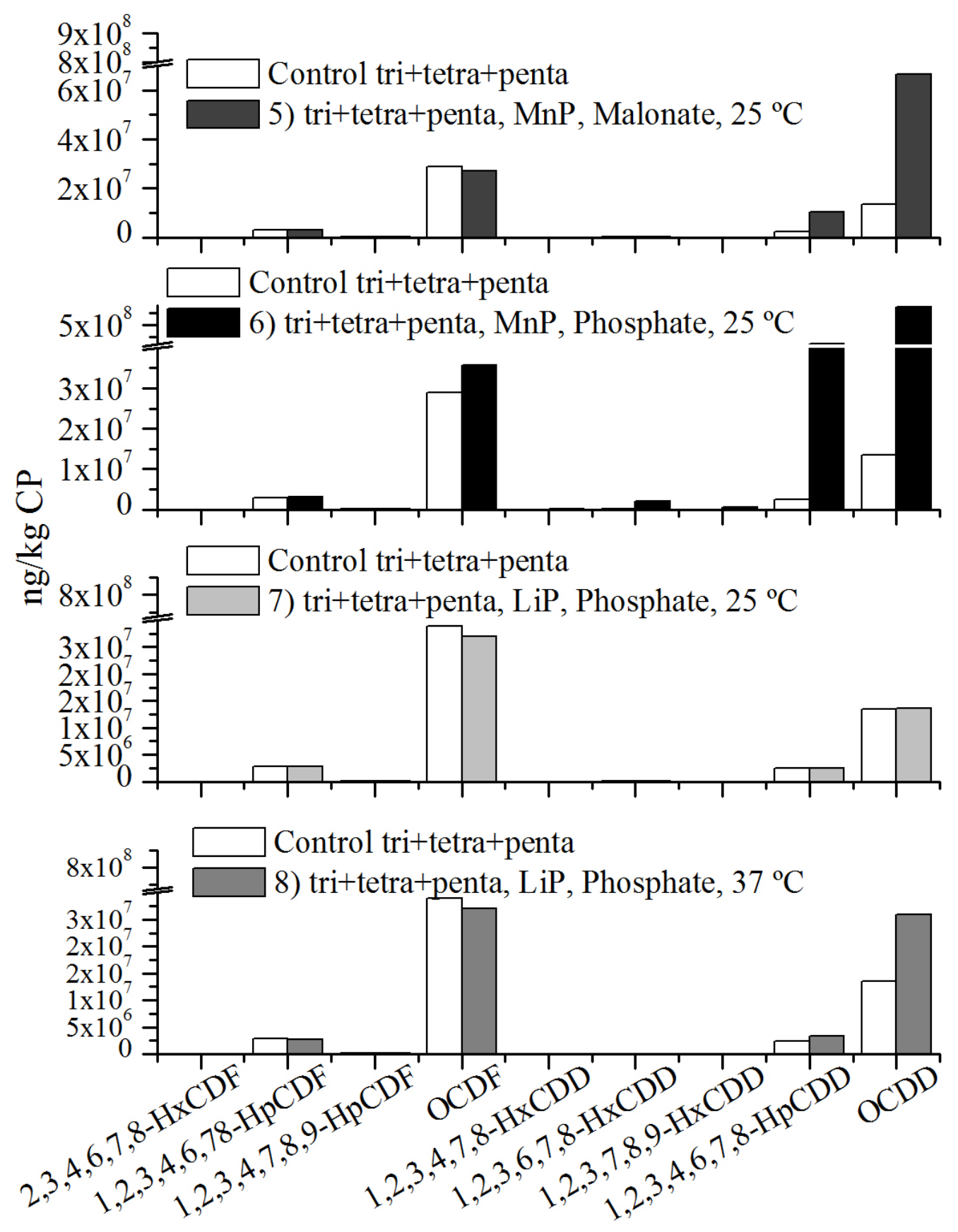

299 Figure 2. Concentration of the most abundant congeners in $\mathrm{ng} / \mathrm{kg}$ chlorophenol for the mixtures "tri+tetra+penta". 
In view of Figure 1 and Figure 2, it can be clearly observed that experiments carried out with MnP show a high increase of HpCDD and OCDD (around $80 \%$ of the total concentration in $\mathrm{ng} / \mathrm{kg}$ is OCDD) for both mixtures, "di+tri" and "tri+tetra+penta". Note that, in the experiment with the mixture "di+tri”" and phosphate buffer a considerable formation of some furans can also be observed. On the contrary, no considerable variation can be observed with LiP in all the conditions studied, included the one carried out at $37^{\circ} \mathrm{C}$.

311 Svenson et al. (1989) firstly found the formation of small amounts of 2,3,7,8tetrasubstituted congeners in the oxidation of 2,4,5-trichlorophenol and horseradish peroxidase. Öberg et al. (1990) found total PCDD/F concentrations of $1.1 \cdot 10^{7} \mathrm{ng} \mathrm{kg-}^{1}$

$314 \mathrm{CP}$ for experiments with lactoperoxidase and 3,4,5-trichlorophenol and $1.0 \cdot 10^{7} \mathrm{ng} \mathrm{kg-}{ }^{1}$ $315 \mathrm{CP}$ with 2,4,5-trichlorophenol with blanks giving no detectable levels. Also an important $\mathrm{PCDD} / \mathrm{F}$ formation is detected in some experiments of this study with the enzyme MnP.

In experiment "tri+tetra+penta, MnP, Phosphate and $25^{\circ} \mathrm{C}$ the concentration of OCDD is more than $8 \cdot 10^{8} \mathrm{ng} \mathrm{kg}^{-1} \mathrm{CP}$ while the initial concentration is $1 \cdot 10^{7} \mathrm{ng} \mathrm{kg}^{-1} \mathrm{CP}$ resulting in an important increase. On the other hand, OCDD concentrations obtained in experiment "tri+tetra+penta, MnP, Malonate and $25^{\circ} \mathrm{C}$ " were more than $6 \cdot 10^{7} \mathrm{ng} / \mathrm{kg}$

$322 \mathrm{CP}$ (around 5 times more than initial sample) which is also much higher than the values reported in literature (Öberg et al., 1992). Öberg et al. (1992) found high amounts of 324 OCDD (more than $6 \cdot 10^{7} \mathrm{ng} \mathrm{kg}_{-}{ }^{1} \mathrm{CP}$ ) in their experiments with PCP and 325 lactoperoxidase.

Regarding the toxicity and as previously commented, only experiments with $\mathrm{MnP}$ and Phosphate buffer result in an increase. Congeners profiles for experiments with $\mathrm{MnP}$ are shown in Figure 3. The experiment "tri+tetra+penta, MnP and Phosphate" 
329 shows the biggest increase from $9 \cdot 10^{4}$ to $181 \cdot 10^{4} \mathrm{ng} \mathrm{WHO}_{2005}$-TEQ $\mathrm{kg}^{-1}$ (Figure 3B)

330 which is due to HpCDD and OCDD congeners. Nevertheless, it can be emphasized that

331 the increase in the total toxicity could be much greater if the toxicity factors of HpCDD

332 and OCDD (0.01 and 0.0003 respectively) were close to the unit.

333 Note how the experiments with the higher chlorinated chlorophenols gave the higher

$334 \mathrm{PCDD} / \mathrm{F}$ formation with higher chlorinated congeners (HpCDD and OCDD).

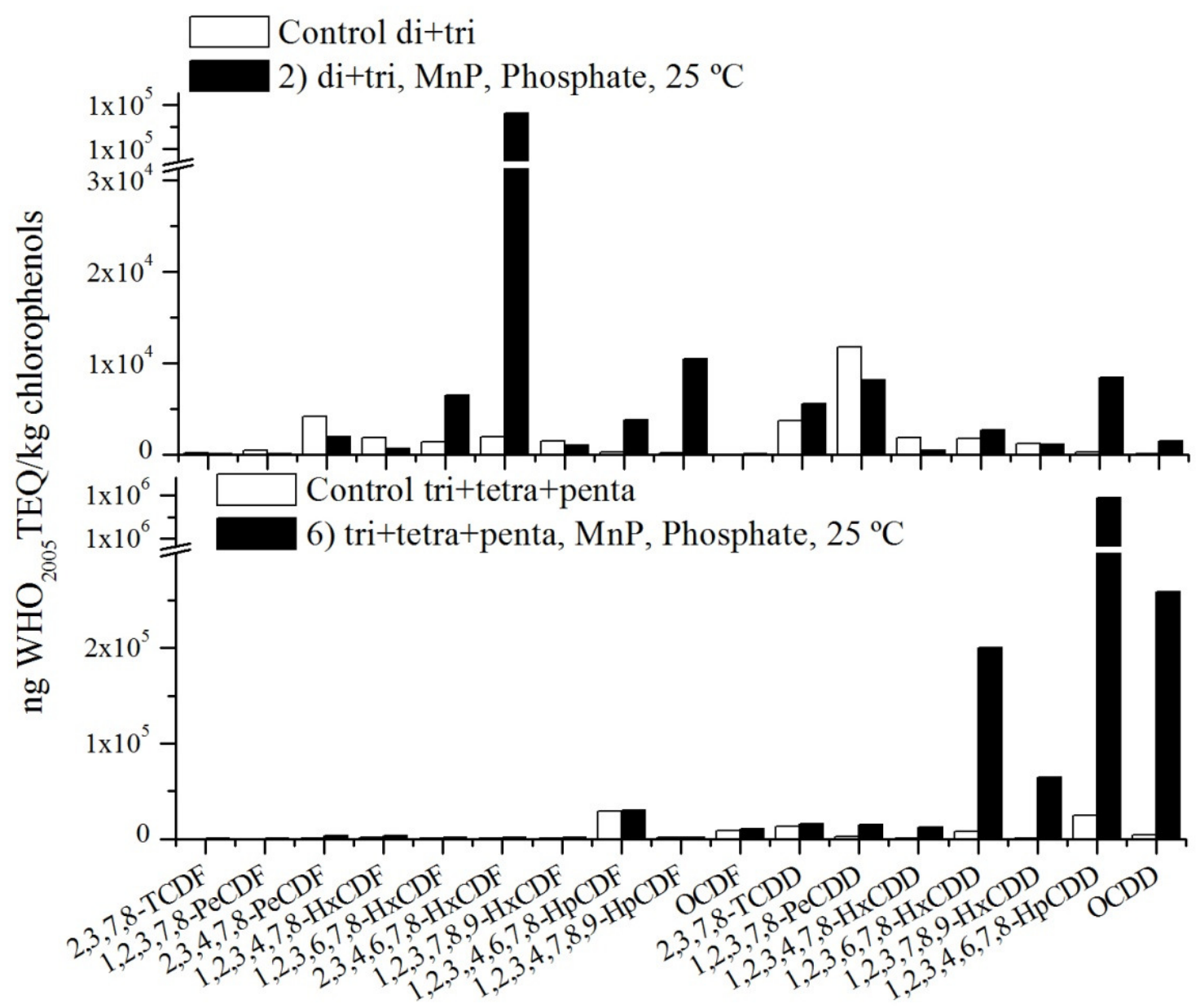

Figure 3. Toxic concentrations for the experiments with an important increase (see nomenclature in 
The results found in this study elucidates a possible enzymatic formation in the 341 compost process at later stages (cooling and maturation stages) as previously reported 342 by Öberg et al. (1994) who found changes in PCDD/Fs in mature garden compost with 343 an increase in the higher chlorinated dioxins. Hamann et al. (1997) also found 344 increasing values in the I-TEQ levels with time in the composting of sewage sludge 345 process and the highest ones were found in the oldest material stored.

346 Experiments with Manganese Peroxidase, which can be found in compost, show a 347 high increase in PCDD/F concentrations, especially in Phosphate buffer and with "tri + 348 tetra + penta" mixture. The PCDD/F concentration in this experiment increased from 349 $6660 \times 10^{4} \mathrm{ng} \mathrm{kg}^{-1} \mathrm{dm}$ to more than $100000 \times 10^{4} \mathrm{ng} / \mathrm{kg} \mathrm{dm}$ and from $9 \times 10^{4}$ to $181 \mathrm{x}$ $35010^{4} \mathrm{ng} \mathrm{WHO}_{2005}$ TEQ $\mathrm{ng} \mathrm{kg}$. The increase in the total toxicity expressed as ng 351 WHO2005 TEQ $\mathrm{kg}^{-1}$ could be much greater if the toxicity factors of HpCDD and 352 OCDD were close to the unit. The results could explain the biogenic formation 353 previously discussed in the literature during later stages of composting. Consequently, the $\mathrm{PCDD} / \mathrm{F}$ formation in the compost depends on the specific conditions related to the highest enzymatic activity and precursors present in the initial sample. Due to this and also to minimize a PCDD/F formation during the process, special attention should be paid at the initial materials used for composting.

\section{Acknowledgments}

The authors want to thank the University of Alicante for their economic support to perform this research and the project CTQ 2008-05520 of the Spanish Ministry of Spain. 
365

366

367

368

369

370

371

372

373

374

375

376

377

378

379

380

381

382

383

384

385

386

387

388

389

390

391

392

393

394

395

396

397

398

399

400

401

402

403

404

405

406

Alam, M. Z.; Mansor, M. and Jalal, K. C. A. (2009) Optimization of lignin peroxidase production and stability by Phanerochaete Chrysosporium using sewage-treatment-plant sludge as substrate in a stirred-tank bioreactor. J Ind Microbiol Biotechnol 36(5): 757764.10.1007/s10295-009-0548-5

Bonnen, A. M.; Anton, L. H. and Orth, A. B. (1994) Lignin-degrading enzymes of the commercial button mushroom, Agaricus bisporus. Appl. Environ. Microbiol. 60(3): 960-965

Chang, Y. S. (2008) Recent developments in microbial biotransformation and biodegradation of dioxins. J Mol Microbiol Biotechnol 15(2-3): 152-171.000121327 [pii]

$10.1159 / 000121327$ [doi]

Concejero, M.; De la Torre, A.; Sanz, P. and Martinez, A. (2008) PCDD/Fs, PCBs and HCB in leachate and compost from different Spanish landfills. Organohalogen Compd. 70: 1773-1775

Czaplicka, M. (2004) Sources and transformations of chlorophenols in the natural $\begin{array}{lllll}\text { environment. Sci. } & \text { Total }\end{array}$ 39.http://dx.doi.org/10.1016/j.scitotenv.2003.09.015

Eibes, G.; Cajthaml, T.; Moreira, M. T.; Feijoo, G. and Lema, J. M. (2006) Enzymatic degradation of anthracene, dibenzothiophene and pyrene by manganese peroxidase in media containing acetone. Chemosphere 64(3): 408-414

Eibes, G.; Lú-Chau, T.; Feijoo, G.; Moreira, M. T. and Lema, J. M. (2005) Complete degradation of anthracene by Manganese Peroxidase in organic solvent mixtures. Enzyme Microb. Technol. 37(4): 365-372

Feijoo, G.; Moreira, M. T.; Alvarez, P.; Lú-Chau, T. A. and Lema, J. M. (2008) Evaluation of the enzyme manganese peroxidase in an industrial sequence for the lignin oxidation and bleaching or eucalyptus kraft pulp. J. Appl. Polym. Sci. 109(2): 1319-1327

Field, J. A. and Sierra-Alvarez, R. (2008) Microbial degradation of chlorinated dioxins. Chemosphere 71(6): 1005-1018.10.1016/j.chemosphere.2007.10.039

Gold, M., H.; Wariishi, H. and Valli, K. (1989) Extracellular peroxidases involved in lignin degradation by the White Rot Basidiomycete Phanerochaete chrysosporium. Biocatalysis in Agricultural Biotechnology 389(389): 127-140.doi:10.1021/bk-19890389.ch009

Gómez-Rico , M. F.; Font, R. and Fullana, A. (2007) Study of PCDD/Fs formation during composting of sewage sludge in different conditions. Organohalogen Compd. 69(P125): $1570-1573$

Hamann, R.; Weber, H.; Disse, G. and Haupt, H. J. (1997) Determination of the PCDD/F levels in large-scale sewage sludge composting. Organohalogen Compd. 32: 400-402

Hatakka, A. (1994) Lignin-modifying enzymes from selected white-rot fungi: Production and role in lignin degradation. FEMS Microbiology Reviews 13(2-3): 125-135

Huwe, J. K.; Feil, V. J.; Zaylskie, R. G. and Tiernan, T. O. (2000) An investigation of the in vivo formation of octachlorodibenzo-p-dioxin. Chemosphere 40(9-11): 957962.10.1016/s0045-6535(99)00339-2

Lankinen, P.; Bonnen, A.; Anton, L.; Wood, D.; Kalkkinen, N.; Hatakka, A. and Thurston, C. (2001) Characteristics and N-terminal amino acid sequence of Manganese Peroxidase 
from solid substrate cultures of Agaricus Bisporus. Appl. Microbiol. Biotechnol. 55(2): 170-176.10.1007/s002530000509

Lankinen, P.; Hildén, K.; Aro, N.; Salkinoja-Salonen, M. and Hatakka, A. (2005) Manganese peroxidase of Agaricus bisporus: grain bran-promoted production and gene characterization. Appl. Microbiol. Biotechnol. 66(4): 401-407.10.1007/s00253-004$1731-2$

Malloy, T. A.; Goldfarb, T. D. and Surico, M. T. J. (1993) PCDDs, PCDFs, PCBs, chlorophenols (CPs) and chlorobenzenes (CBzs) in samples from various types of composting facilities in the United States. Chemosphere 27(1-3): 325-334.10.1016/0045-6535(93)90309-s

Mester, T. and Tien, M. (2000) Oxidation mechanism of ligninolytic enzymes involved in the degradation of environmental pollutants. International Biodeterioration \&amp; Biodegradation 46(1): 51-59

Novotný, Č.; Svobodová, K.; Erbanová, P.; Cajthaml, T.; Kasinath, A.; Lang, E. and Šašek, V. (2004) Ligninolytic fungi in bioremediation: extracellular enzyme production and degradation rate. Soil Biology and Biochemistry 36(10): 15451551.http://dx.doi.org/10.1016/j.soilbio.2004.07.019

Öberg, L. G.; Glas, B.; Swanson, S. E.; Rappe, C. and Paul, K. G. (1990) Peroxidase-catalyzed Oxidation of Chlorophenols to Polychlorinated Dibenzo-p-dioxinas and Dibenzofurans. Arch. Environ. Contam. Toxicol. 19: 930-938

Öberg, L. G. and Rappe, C. (1992) Biochemical formation of PCDD/Fs from chlorophenols. Chemosphere 25(1-2): 49-52

Öberg, L. G. and Swanson, S. E. (1987) On the absence of polychlorinated dibenzodioxins and dibenzofurans after lactoperoxidase-catalyzed transformation of chlorophenols. Bull. Environ. Contam. Toxicol. 38(6): 962-968.10.1007/bf01609081

Öberg, L. G.; Wagman, N.; Andersson, R. and Rappe, C. (1993) De novo formation of PCDD/Fs in compost and sewage sludge - a status report. Organohalogen Compd. 11: 297-302

Öberg, L. G.; Wagman, N.; Koch, M. and Rappe, C. (1994) Polychlorinated dibenzo-p-dioxins, dibenzofurans and non-ortho PCBs in household organic-waste compost and mature garden waste compost. Organohalogen Compd. 20: 245-250

Oleszczuk, P. (2007) Changes of polycyclic aromatic hydrocarbons during composting of sewage sludge with chosen physico-chemical properties and PAHs content. Chemosphere 67: 582-591

Ozkaya, B. (2005) Chlorophenols in leachates originating from different landfills and aerobic composting plants. J. Hazard. Mater. 124(1-3): 107112.http://dx.doi.org/10.1016/j.jhazmat.2005.04.016

Pointing, S. (2001) Feasibility of bioremediation by white-rot fungi. Appl. Microbiol. Biotechnol. 57(1-2): 20-33.10.1007/s002530100745

Quintero, J. C.; Feijoo, G. and Lema, J. M. (2006) Producción de enzimas Lignolíticas con hongos basidiomicetos cultivados sobre materiales lignocelulósicos. VITAE 13(2): 61-67

Sedarati, M. R.; Keshavarz, T.; Leontievsky, A. A. and Evans, C. S. (2003) Transformation of high concentrations of chlorophenols by the white-rot basidiomycete Trametes versicolor immobilized on nylon mesh. Electronic Journal of Biotechnology 6: 104-114

Suhara, H.; Kamei, I.; Maekawa, N. and Kondo, R. (2011) Biotransformation of polychlorinated dibenzo-p-dioxin by Coprinellus species. Mycoscience 52(1): 4852.http://dx.doi.org/10.1007/S10267-010-0062-7 
476

Svenson, A.; Kjeller, L. O. and Rappe, C. (1989) Enzyme-mediated formation of 2,3,7,8tetrasubstituted chlorinated dibenzodioxins and dibenzofurans. Environmental Science \& Technology 23(7): 900-902.10.1021/es00065a022

ten Have, R.; Wijngaard, H.; Ariës-Kronenburg, N. A. E.; Straatsma, G. and Schaap, P. J. (2003) Lignin degradation by Agaricus bisporus accounts for a 30 increase in bioavailable holocellulose during cultivation on compost. J. Agric. Food Chem. 51(8): 22422245.10.1021/jf021131h

Tuomela, M.; Vikman, M.; Hatakka, A. and Itävaara, M. (2000) Biodegradation of lignin in a compost environment: a review. Bioresour. Technol. 72(2): 169-183.10.1016/s09608524(99)00104-2

US EPA (1994). Method 1613. Tetra- through Octa-Chlorinated Dioxins and Furans by Isotope Dilution HRGC/HRMS. SW-846. Washington, D.C., U.S. Environmental Protection Agency.

Wagner, H. C.; Schramm, K. W. and Hutzinger, O. (1990) Biogenic polychlorinated dioxin and furan from trichlorophenol. Organohalogen Compd. 3: 453-456

Weber, H.; Hamann, R.; Disse, G. and Haupt, H. J. (1997) Influence of different treatment methods for sewage sludge on the levels of chlorinated dibenzodioxins and dibenzofurans. Organohalogen Compd. 32: 394-399

Wittsiepe, J.; Kullmann, Y.; Schrey, P.; Selenka, F. and Wilhelm, M. (2000) Myeloperoxidasecatalyzed formation of PCDD/F from chlorophenols. Chemosphere 40(9-11): 963-968

Yoshida, S.; Watanabe, T.; Honda, Y. and Kuwahara, M. (1997) Effects of water-miscible organic solvents on the reaction of lignin peroxidase of Phanerochaete chrysosporium. Journal of Molecular Catalysis B: Enzymatic 2(4-5): 243-251 